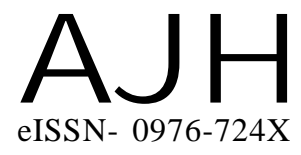

Received : 25.08.2017

Revised : 07.11.2017

Accepted : 14.11 .2017
Members of the Research Forum

Associated Authors:

${ }^{1}$ AICRP-Floriculture, B.C.K.V.,

NADIA (W.B.) INDIA

${ }^{2}$ Department of Floriculture and LSD, Bidhan Chandra Krishi Viswavidyalaya, Mohanpur, NADIA (W.B.) INDIA

${ }^{3}$ Department of Agronomy, Bidhan Chandra Krishi Viswavidyalaya, Mohanpur, NADIA (W.B.) INDIA

Author for correspondence : T. K. CHOWDHURI AICRP-Floriculture, B.C.K.V., NADIA (W.B.) INDIA Email : tkc.hort@gmail.com
THEASIAN JOURNALOF HORTICULTURE

Volume 12 | Issue 2 | December, 2017 | 206-210

Visit us -www.researchjournal.co.in

RESEARCH PAPER

DOI : 10.15740/HAS/TAJH/12.2/206-210

\section{Effect of different growth regulators on propagation of Cape jasmine (Tabenaemontana coronaria var.Dwarf) in subtropical zone of West Bengal}

\section{T. K. CHOWDHURI, R. SADHUKHAN ${ }^{1}$, T. MONDAL ${ }^{2}$ AND S. DAS ${ }^{3}$}

ABSTRACT : The present investigation was carried out to study the effect of different growth regulators on propagation of tagor (Tabenaemontana coronaria var. Dwarf) in subtropical zone of West Bengal under natural ventilated polyhouse at Mondari farm of Bidhan Chandra Krishi Viswavidyalaya, Mohanpur, Nadia, West Bengal, during 2014-15 and 2015-16. All parameters were significantly varied among the treatments during investigation $\left(T_{1}:\right.$ IAA @ 1000 ppm, T: IAA@2000ppm, T. IAA @3000ppm, T. IBA @ 1000ppm, T: IBA @2000ppm, T6: IBA @

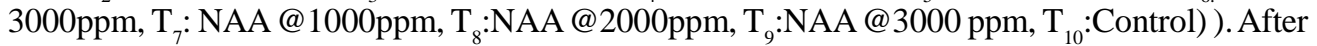
studying of two consecutive years, it has been found that NAA at higher concentration is best for plant multiplication of tagor during rainy season in subtropical zone of West Bengal followed by IAA and IBA at $3000 \mathrm{ppm}$. Tip cuttings and semi hard wood cuttings of tagor were markedly influence in terms highest number of plant and quality of plant production, respectively.

KEY WORDS : Tabenaemontana coronaria var. Dwarf, Propagation, Growth regulators, Subtropical zone

HOW TO CITE THIS ARTICLE : Chowdhuri, T.K., Sadhukhan, R., Mondal, T. and Das, S. (2017). Effect of different growth regulators on propagation of Cape jasmine (Tabenaemontana coronaria var. Dwarf) in subtropical zone of West Bengal. Asian J. Hort., 12(2) : 206-210, DOI : 10.15740/HAS/ TAJH/12.2/206-210. 